\title{
NILAI-NILAI SHINTOISME PADA PERBEDAAN WARNA DAN BENTUK GERBANG DUNIA DEWA DI AWAL DAN AKHIR FILM SPIRITED AWAY KARYA STUDIO GHIBLI
}

\author{
Maugina Rizki Havier, M.Ds \\ Program Studi Desain Interior, Fakultas Arsitektur dan Desain, ITENAS, Bandung \\ Email: maugina.havier@itenas.ac.id
}

\begin{abstract}
Abstrak
Spirited Away merupakan film animasi yang diproduksi pada tahun 2001 oleh Studio Ghibli di bawah arahan sutradara Hayao Miyazaki. Film ini berhasil meraih penghargaan Academy Award ke-75 untuk kategori Film Animasi Terbaik. Film ini mengisahkan tentang Chihiro, tokoh utama yang terjebak masuk ke dalam dunia Dewa/roh (spirited away). Terdapat perbedaan yang cukup signifikan pada desain arsitektur gerbang yang Chihiro masuki di awal film dan pada saat dia keluar di akhir film. Keadaan, warna, dan desain gerbang tersebut sama sekali berbeda, walaupun itu adalah gerbang yang sama di lokasi yang sama. Arti dari perbedaan ini tidak pernah dijelaskan secara eksplisit oleh Studio Ghibli ataupun Hayao Miyazaki. Peneliti menganalisa kedua desain gerbang untuk mengetahui tujuan dan arti perbedaan desain tersebut. Penelitian ini bersifat kualitatif, dimana peneliti menganalisis desain arsitektural kedua gerbang dengan Metode Analisis Semiotika Komunikasi Visual, mencari tanda, kode, dan arti visual dari warna dan bentuk gerbang, serta konsep film Spirited Away, berdasarkan ciri-ciri arsitektural bangunan tradisional Jepang dan nilai-nilai dari Kepercayaan Shinto (Shintoisme). Analisis visual ini juga memanfaatkan beberapa poin analisa pada Konsep Triadik Sumbo Tinarbuko, diantaranya analisis yang dihasilkan dari studi literatur, analisa konten visual dan konteks film, serta media yang dipakai. Hasil analisis yang muncul dari perbedaan desain gerbang tersebut berfungsi untuk memperlihatkan "apa, siapa, dan waktu" penyambutan yang diwakilkan oleh desain gerbang. Perbedaan ini berhubungan erat dengan konteks dan konten keseluruhan film tersebut, serta untuk menunjukan status dari dunia yang dimasuki oleh Chihiro dan keluarganya. Hasil analisis ini diharapkan memberi informasi baru untuk penelitian sejenis dan juga dapat memberikan informasi untuk pengembangan desain arsitektur dalam dunia animasi, khususnya yang berhubungan dengan bangunan tradisional ataupun spiritual pada suatu daerah tertentu.
\end{abstract}

Kata kunci: Spirited Away, Ghibli, Arsitektur, Shintoisme, Gerbang

\begin{abstract}
Spirited Away is an animation made by Ghibli Studio in 2001 under Hayao Miyazaki's direction. This movie was awarded as The Best Animation by The 75th Academy Award. The movie tells about the journey of Chihiro, the protagonist who's been "spirited away" to the spirit world. There's a significant difference in the visual and surrounding of the scene when Chihiro went inside the spirit world through the gate at the beginning of the movie and when she's back from that world at the ending. The environment, color, and design of the gate seem to be different even though it's the same gate at the same place. The importance of these distinctions was never explained explicitly by Ghibli Studio or Hayao Miyazaki. The researcher analyzes both gates to find the meaning and purpose of the distinction. This is qualitative research, where researcher analyze architectural design both gate with semiotic visual communication analytic method, finding symbol, code, and visual meaning from color, form, and the concept of Spirited Away movie, by characteristic features of Japanese traditional building and Shinto's Perspective (Shintoism). This visual analysis also utilizes some analytic points of Sumbo Tinarbuko's Triadic Concept, which are literature study analytic, visual content analytic, film context, and the media used. The results from the analysis are that the gate design distinction is functioned to show the difference of "what, who, and when" the gate welcoming the guests. The distinction is closely related to the contexts and content of the whole movie, and to show the status of Spirit World which Chihiro and her family entered. This result is expected to give new information for research of a kind, and give information for architecture design on animation related with traditional and spiritual building particularly.
\end{abstract}

Keywords: Spirited Away, Ghibli, Architecture, Shintoism, Gate 


\section{Pendahuluan}

\subsection{Film Spirited Away}

Spirited Away merupakan film animasi karya Studio Ghibli yang dikenal dunia animasi internasional secara sporadis sejak memenangkan penghargaan Academy Award yang ke-75 untuk kategori Film Animasi Terbaik. Spirited Away diproduksi Page | 38 pada tahun 2001 oleh Studio Ghibli di bawah arahan sutradara Hayao Miyazaki. Film yang berdurasi 125 menit ini memiliki judul asli “Sen To Chihiro No Kamikakushi” (千と千尋の神隠し)[1] dan secara global dipasarkan dengan judul Spirited Away.
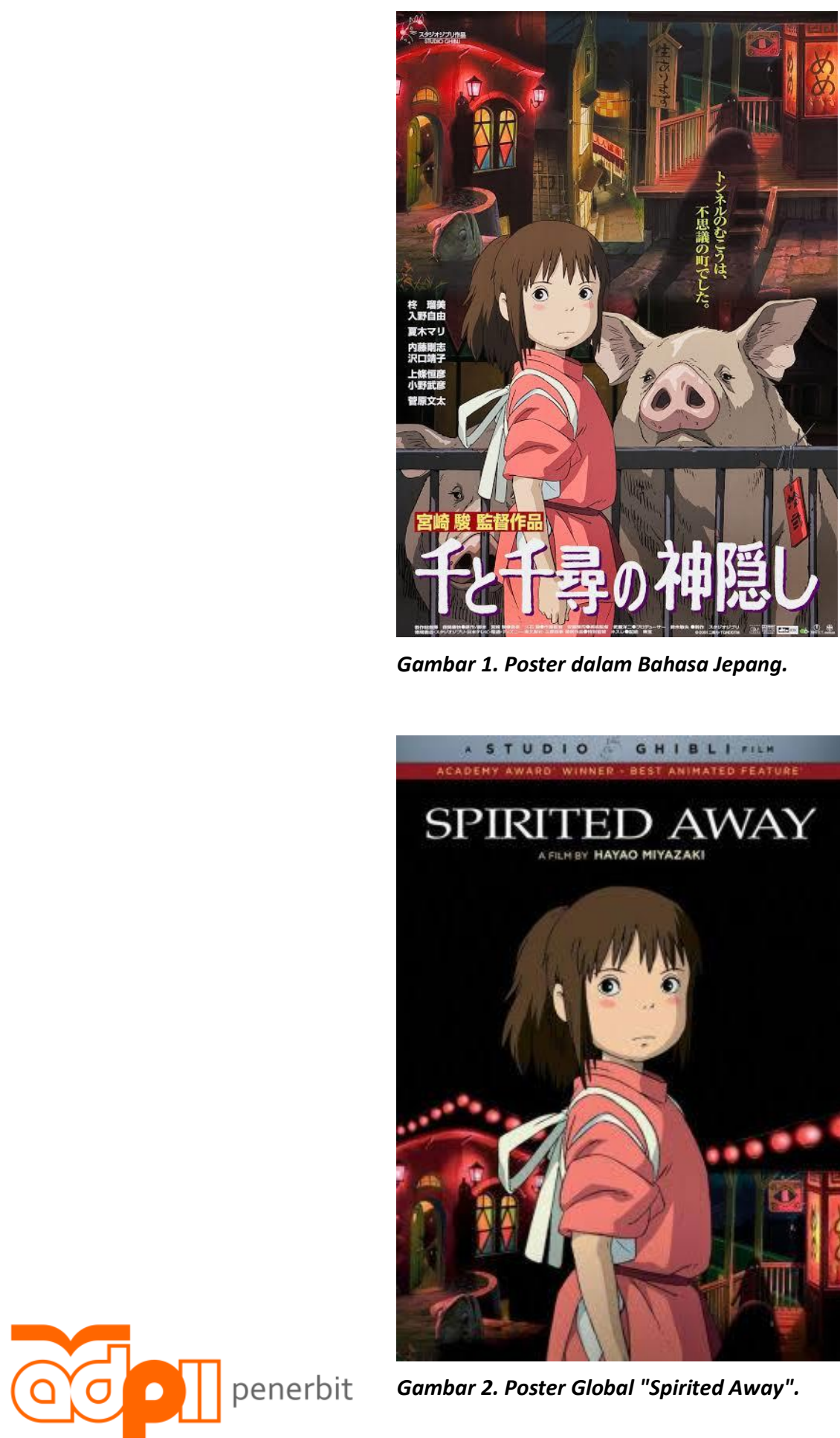

Gambar 1. Poster dalam Bahasa Jepang.

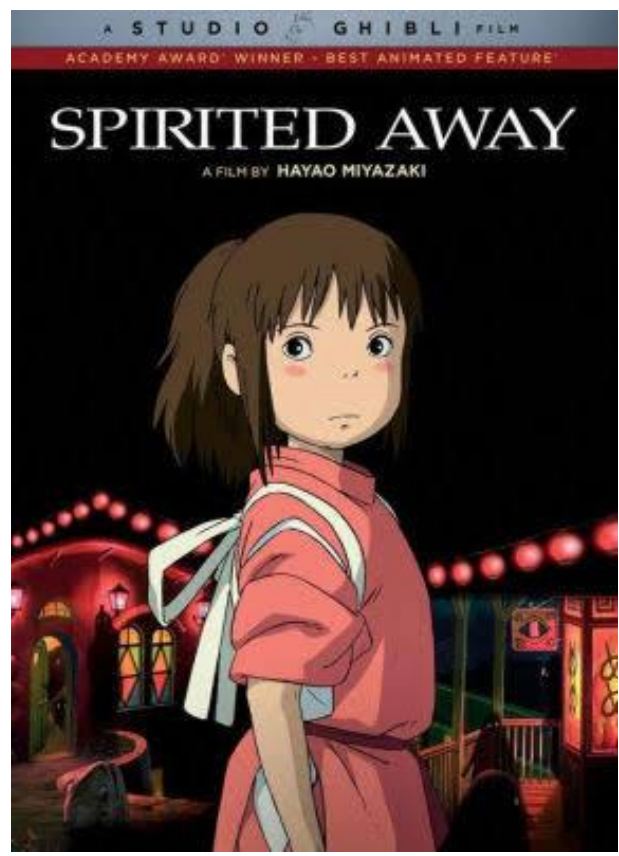

Gambar 2. Poster Global "Spirited Away". 
Film ini mengisahkan tentang seorang anak bernama Chihiro yang melakukan perjalanan bersama orang tuanya menuju rumah baru mereka. Dalam perjalanan, mereka masuk ke dalam sebuah tempat yang tampak seperti taman bermain yang telah bangkrut, melewati gerbang besar berwarna merah yang dijaga patung batu dengan dua wajah yang disebut Dosojin. Gerbang tersebut berbentuk lorong panjang yang gelap dan berakhir di ruang tunggu stasiun kereta bergaya klasik. Mereka terus masuk dan menemukan komplek pertokoan dan rumah makan, salah satunya menyediakan berbagai jenis makanan lezat tanpa penjaga dan membuat kedua orang tua Chihiro lapar. Mereka memakannya tanpa mengindahkan keadaan. Chihiro yang merasa resah tidak ikut makan, dia berkeliling melihat tempat yang sangat sepi itu, dan mendapati sebuah istana bertuliskan "bathhouse"/Pemandian, dan sebuah kereta api melintas di bawah jembatan yang mengarah ke istana tersebut. Disana dia bertemu Haku yang akhirnya akan menjadi temannya. Haku menyuruh Chihiro pergi, namun terlambat, orangtua Chihiro telah dikutuk menjadi babi dan diapun terjebak di dunia tersebut bersama dewa-dewa dan roh. Dengan bantuan Haku, Chihiro bertahan hidup di dunia tersebut dengan cara bekerja di dalam bathhouse sambil berusaha untuk menyelamatkan kedua orang tuanya, dan keluar dari dunia itu bersama-sama.

Di awal film, gerbang yang dimasuki Chihiro dan keluarganya digambarkan dengan warna merah dan gaya arsitektural yang terkesan seperti karakteristik kuil-kuil Shinto di Jepang. Sedangkan di akhir film mereka keluar di tempat yang sama namun desain gerbang tersebut berubah menjadi susunan batu putih biasa dengan keadaan lingkungan yang terbengkalai. Tidak ada penjelasan dalam film mengenai perbedaan desain arsitektural tersebut. Apakah keluarga Chihiro keluar dari dunia dewa ke dunia manusia di dimensi lain? Apakah mereka keluar di tempat yang berbeda? Apakah sebetulnya keluarga Chihiro tidak kembali ke dunia manusia? Apakah arti sebenarnya dari perbedaan desain gerbang tersebut di awal dan akhir film? Untuk mengetahui tujuan perbedaan desain tersebut, peneliti meneliti visual dari kedua desain gerbang dengan menggunakan Metode analisis semiotika komunikasi visual, mendeskripsikan visual dari kedua desain gerbang, tanda-tanda visual dan kode yang muncul di sepanjang film baik itu dari segi arsitektural maupun konsep cerita dalam film, serta melihat dari nilai-nilai shintoisme, sehingga arti perbedaan desain gerbang tersebut dapat disimpulkan. Kesimpulan ini dapat memberikan hipotesa terhadap arti tersembunyi dari film Spirited Away yang berhubungan dengan desain arsitektural gerbang tersebut. Hasil penelitian ini juga dapat memberikan kontribusi berupa informasi visual terhadap potensi pengembangan desain arsitektural dalam film animasi, khususnya yang berhubungan dengan nilai-nilai tradisional ataupun spiritual pada suatu daerah.

\section{Metodologi}

Penelitian ini bersifat kualitatif dengan menggunakan metode analisis semiotika komunikasi visual pada kedua desain gerbang dilihat dari warna, bentuk, material, dan arsitektural serta nilai historis maupun spiritual di dalamnya. Studi literatur meliputi arsitektural Jepang, Shintoisme, dan juga teori warna yang dikaitkan dengan hal tersebut. Selain studi literatur, pencarian data kualitatif juga dilakukan dengan mengakses situs resmi dari Studio Ghibli dan website fandom beserta artikel-artikel terkait Studi Ghibli, khususnya film Spirited Away.

Metode analisis semiotika komunikasi visual pada dasarnya beroperasi pada dua jenjang analisis. Yang pertama yaitu analisis tanda secara individual yang mencakup tanda, kode, dan makna tanda, dan kedua adalah analisis tanda yang membentuk teks [2]. Penelitian ini akan lebih fokus pada metode jenjang analisis pertama, peneliti akan menganalisis tanda, kode, dan makna tanda pada desain arsitektural kedua gerbang yang menjadi objek penelitian yang dilihat dari warna, bentuk, konsep film, dan nilai-nilai shintoisme. 


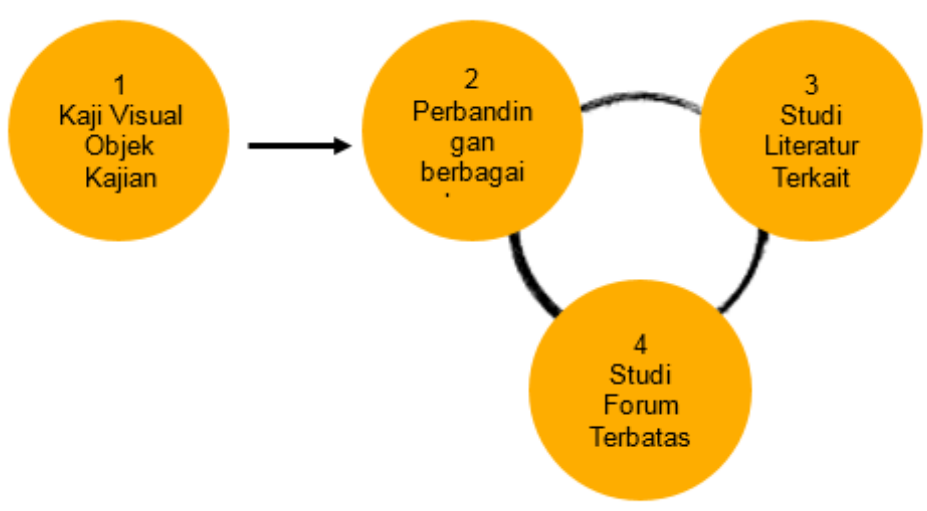

Bagan. 1 Konsep Triadik Sumbo Tinarbuko, Sumber: Tinarbuko (2016), dikomposisikan kembali oleh pribadi (2021)

Agustina (2019) dalam penelitiannya mengidentifikasi bahwa sumber literasi paling efektif untuk mendukung multiliterasi desain adalah gabungan dari beberapa modal literasi, yang bisa merupakan multimodal, diantaranya sumber visual, spasial, dan gestural. Hal ini dapat dicapai dengan peningkatan kerangka berpikir yang intergative, multidisiplin, holistik-saintifik dan konstekstual, salah satunya dari tradisi semiotika [3]. Sehingga dalam menganalisis objek penelitian ini, peneliti juga akan memanfaatkan beberapa poin analisa pada Konsep Triadik Sumbo Tinarbuko[4], diantaranya analisis yang dihasilkan dari studi literatur, analisa konten visual dan konteks film, serta media yang dipakai. Hasil analisis yang muncul merupakan gabungan informasi dari keempat poin tersebut.

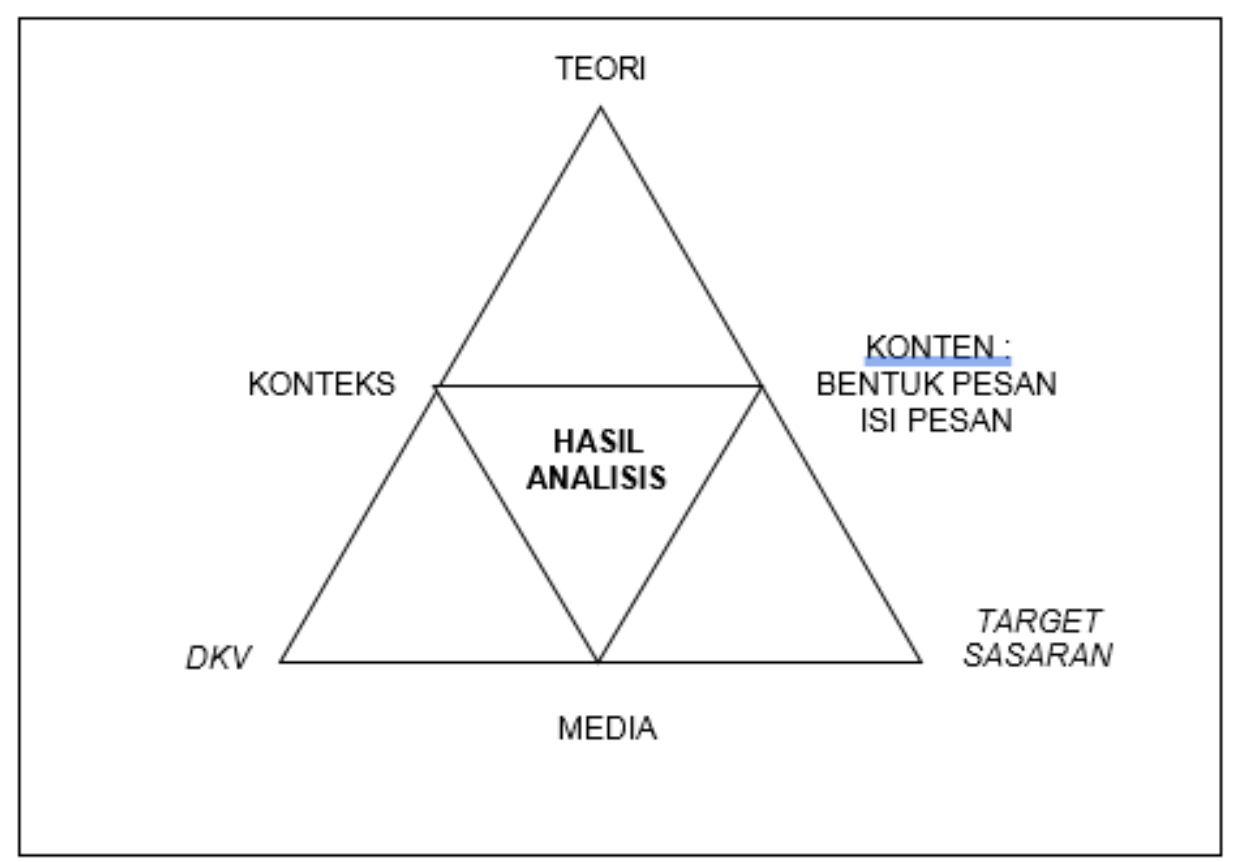

Bagan. 2 Konsep Triadik Sumbo Tinarbuko, Sumber: Tinarbuko (2016), dikomposisikan kembali oleh pribadi (2021)

\section{Diskusi}

\subsection{Nilai-nilai Shintoisme Pada Film Spirited Away}

Shintoisme (agama Shinto) pada mulanya merupakan perpaduan antara paham serba jiwa (animisme) dengan pemujaan terhadap gejala-gejala alam. Shintoisme dipandang oleh bangsa Jepang sebagai suatu agama tradisional 
warisan nenek moyang yang telah berabad-abad hidup di Jepang, bahkan paham ini timbul dari mitos-mitos yang berhubungan dengan terjadinya negara Jepang [5]. Film Spirited away sangat kental dengan nilai-nilai ajaran Shinto. Selain dari arsitektural bangunan-bangunan di dalam film, hal ini juga terlihat dari alur dan lokasi cerita, dimana dunia tempat Chihiro terjebak merupakan tempat para dewa plesir atau membersihkan diri [6]. Beberapa isu yang diangkat secara eksplisit juga bertema tentang lingkungan, seperti pada saat Dewa Sungai yang kotor dan berbau busuk berusaha membersihkan diri di pemandian, ternyata dia dipenuhi oleh sampah buangan manusia seperti sepeda, elektronik, dan sampah domestik lainnya. Setelah bersih, Dewa kotor dan bau itu digambarkan kembali pada wujud aslinya yang Agung : Dewa Sungai. Hal ini seakan ingin menunjukan bahwa kita telah mengotori alam sebegitu parahnya, sehingga spiritual alam terganggu dan membutuhkan pembersihan, karena dunia merupakan tempat dimana semua hal terkait satu sama lain, termasuk manusia dan lingkungan.

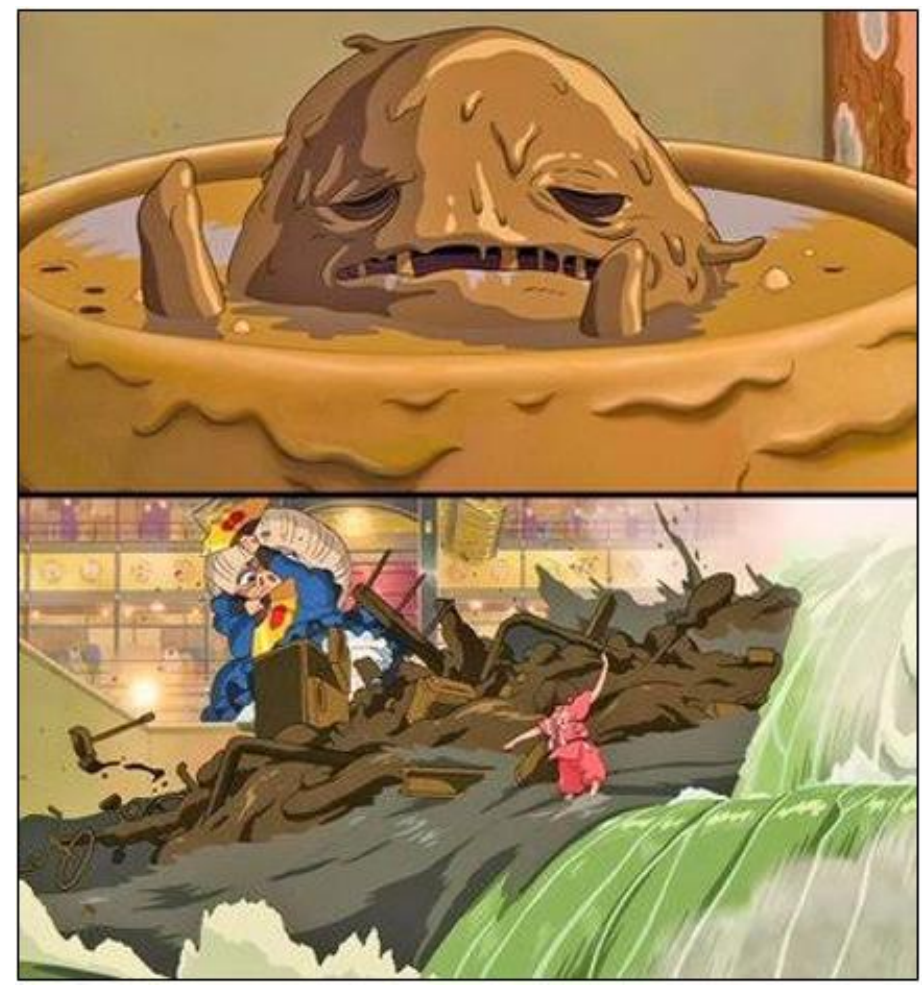

Gambar 3. Adegan dewa bau mandi dan membersihkan diri.

Sumber : https://ew.com/gallery/hayao-miyazakis-16-best-creations/, diakses pada tanggal 02 oktober 2019, pukul 11.51 wib. 


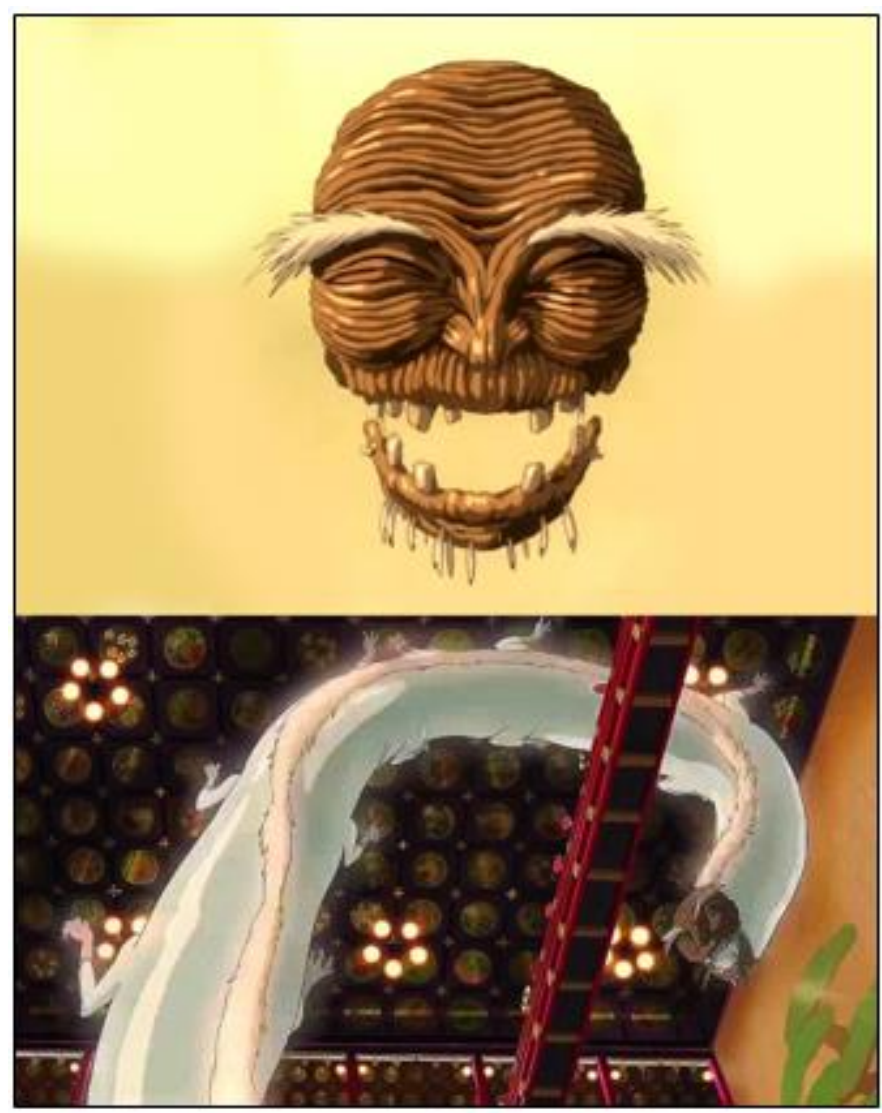

Gambar 4. Dewa Bau yang ternyata adalah Dewa Sungai yang menjadi kotor karena ulah manusia.

Sumber: http://www.cornel1801.com/animated/Spirited-Away-2001/08-Gold-from-guest/videoquotes.html diakses pada tanggal 02 Oktober 2019, Pukul 11.54 WIB 


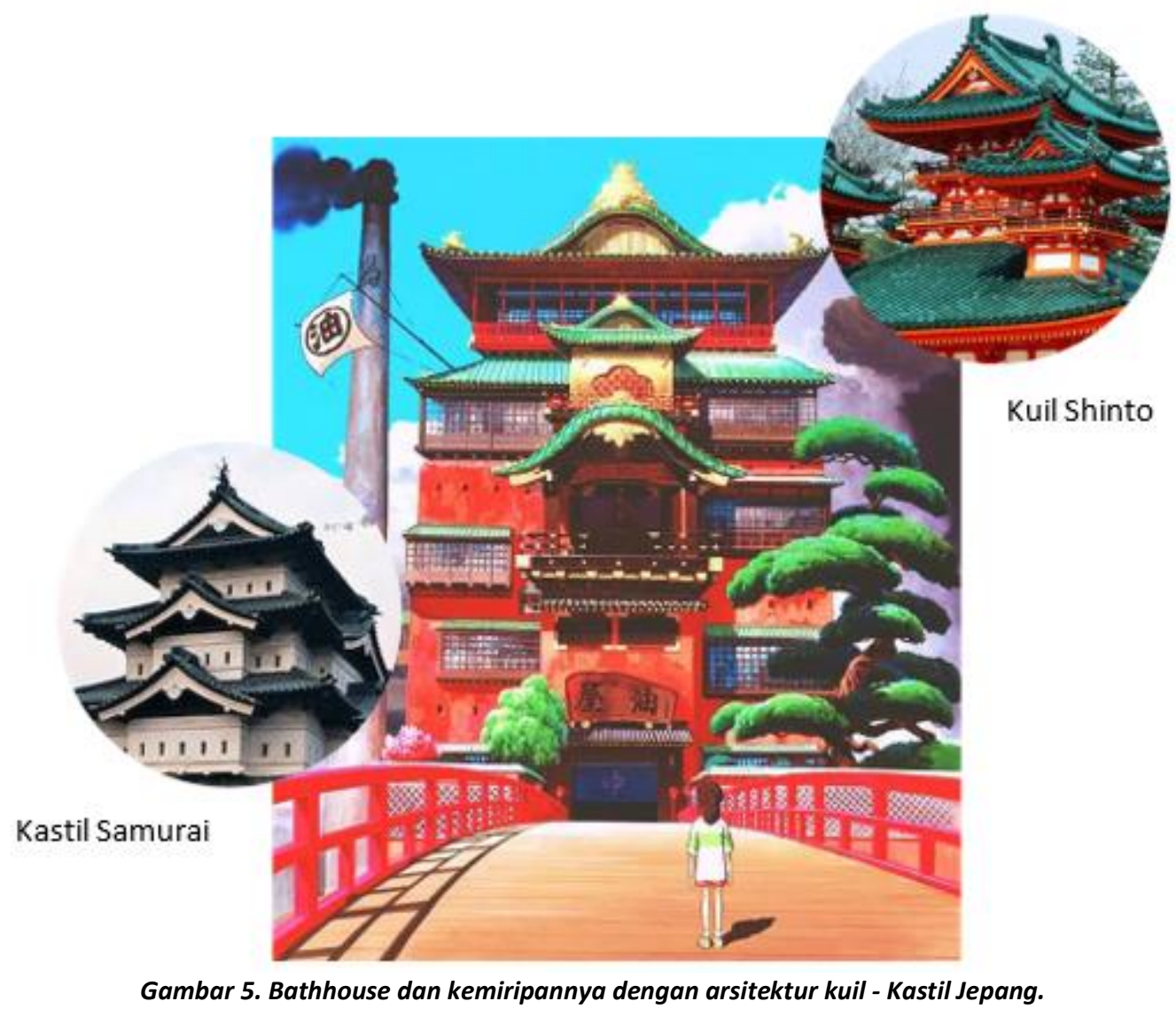

Page $\mid 43$

Sumber: https://www.where-is-this.com, myanimelist.net, https://theculturetrip.com, diakses pada 30 September 2019, pukul 12.50 WIB, dikomposisikan oleh pribadi. 2019

\subsection{Arsitektur dan Shintoisme Pada Desain Gerbang Dunia Dewa}

Dalam film Spirited Away, banyak gedung dan bangunan yang mengambil referensi dari arsitektural tradisional Jepang, khususnya yang berhubungan dengan Shintoisme, seperti kuil, torii, dan kastil. Contohnya adalah desain Pemandian (Bathhouse) yang memiliki beberapa kemiripan dengan kuil-kuil jepang dari segi bentuk dan warna. Berbagai tanda dan kode pada bangunan-bangunan dan karakter dalam film merepresentasikan shintoisme, dilihat dari bentuk gerbang, warna merah yang identik dengan bangunan kuil, patung-patung Dewa dan hokora (minatur kuil shinto), dan karakterkarakter representasi Dewa dan Roh yang ada dalam film. Nuansa Shintoisme yang kental pada film ini juga dapat menjadi petunjuk untuk mengurai arti dari desain arsitektural gerbang yang berbeda di awal dan akhir film.

Salah satu arsitektur bangunan yang cukup menonjol dalam cerita, adalah "Bathhouse" atau Pemandian yang menjadi tempat Chihiro (tokoh utama) bekerja setelah terdampar di dunia tersebut.

Bangunan Pemandian dibuat sangat megah dengan gaya arsitektural kuil Jepang, menegaskan statusnya sebagai tempat yang istimewa dan sakral. Megah direpresentasikan dari bentuk atap yang berundak-undak bagaikan kastil. Tempat ini juga terasa sakral dari warna yang dipakai, karena warna merah pada bangunan Jepang biasanya merepresentasikan kuil dan bangunan sakral lainnya seperti Torii (gerbang), berbeda dengan kastil yang biasanya didominasi warna putih dan hitam. Untuk menuju bangunan tersebut, terdapat sebuah jembatan dengan pagar kayu yang juga diwarnai merah. Pemandian dibuat dengan desain yang sedemikian rupa untuk memperlihatkan statusnya dalam dunia Dewa/roh tersebut, dimana tempat tersebut merupakan tempat ekslusif bagi para Dewa untuk memandikan diri mereka secara nyaman dengan pelayanan tingkat atas. Fasilitas yang ada dalam Pemandian diantaranya : Bathtube pribadi bergaya 
tradisional dengan berbagai kelas dan tingkatan, Restoran untuk pesta, asrama pegawai, ruang uap, dapur, dan di tempat paling atas adalah tempat tinggal Yubaba, penyihir kuat pemilik bangunan tersebut dan juga penguasa dunia itu. Pada dasarnya, ini merupakan istana Yubaba.

Gerbang tempat Chihiro masuk juga digambarkan dengan warna dan bentuk dasar dari kuil-kuil Shinto. Dengan warna merah dan bentuk balok kayu pada bagian atasnya, ditambah patung batu yang terkesan sebagai penjaga gerbang, memberikan kesan bahwa gerbang tersebut adalah gerbang spesial yang sakral. Tanda dan kode yang menguatkan nuansa Shintoisme pada gerbang merah ini adalah Torii dan Hokora yang dilewati oleh keluarga Chihiro sebelum sampai di depan pintu gerbang ini. Torii identik dengan gerbang menuju kuil shinto, sedangkan Hokora adalah minatur dari kuil shinto, yang sering ditemukan di beberapa tempat umum.

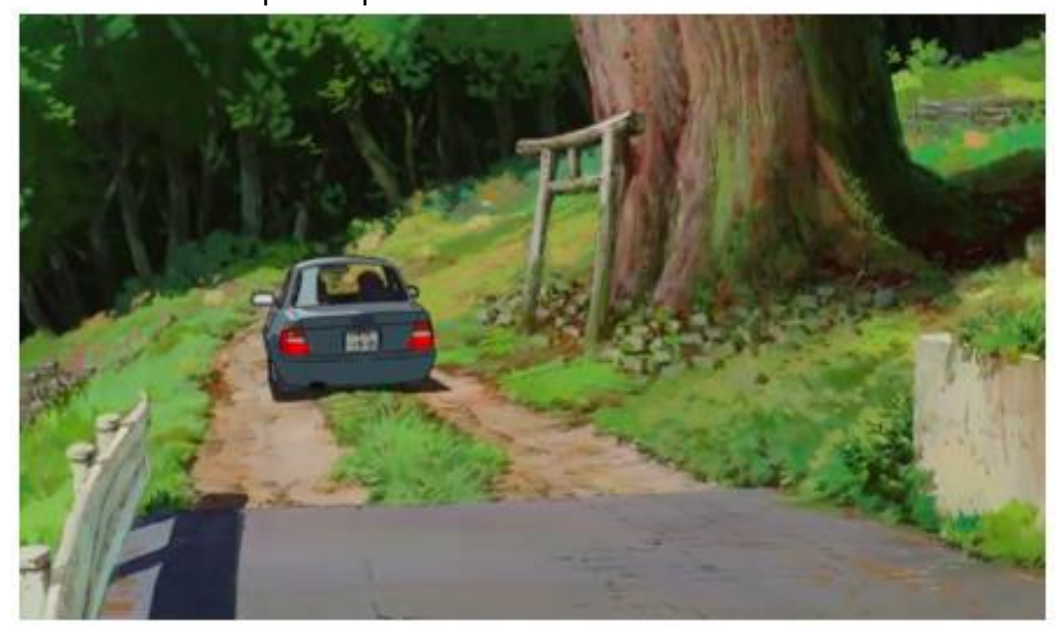

Gambar 6. Torii yang dilewati keluarga Chihiro sebelum sampai Gerbang Merah (Red Gate)

Sumber: https://www.patheos.com, diakses pada tanggal 23 Mei 2021, pukul 18.10 WIB. 


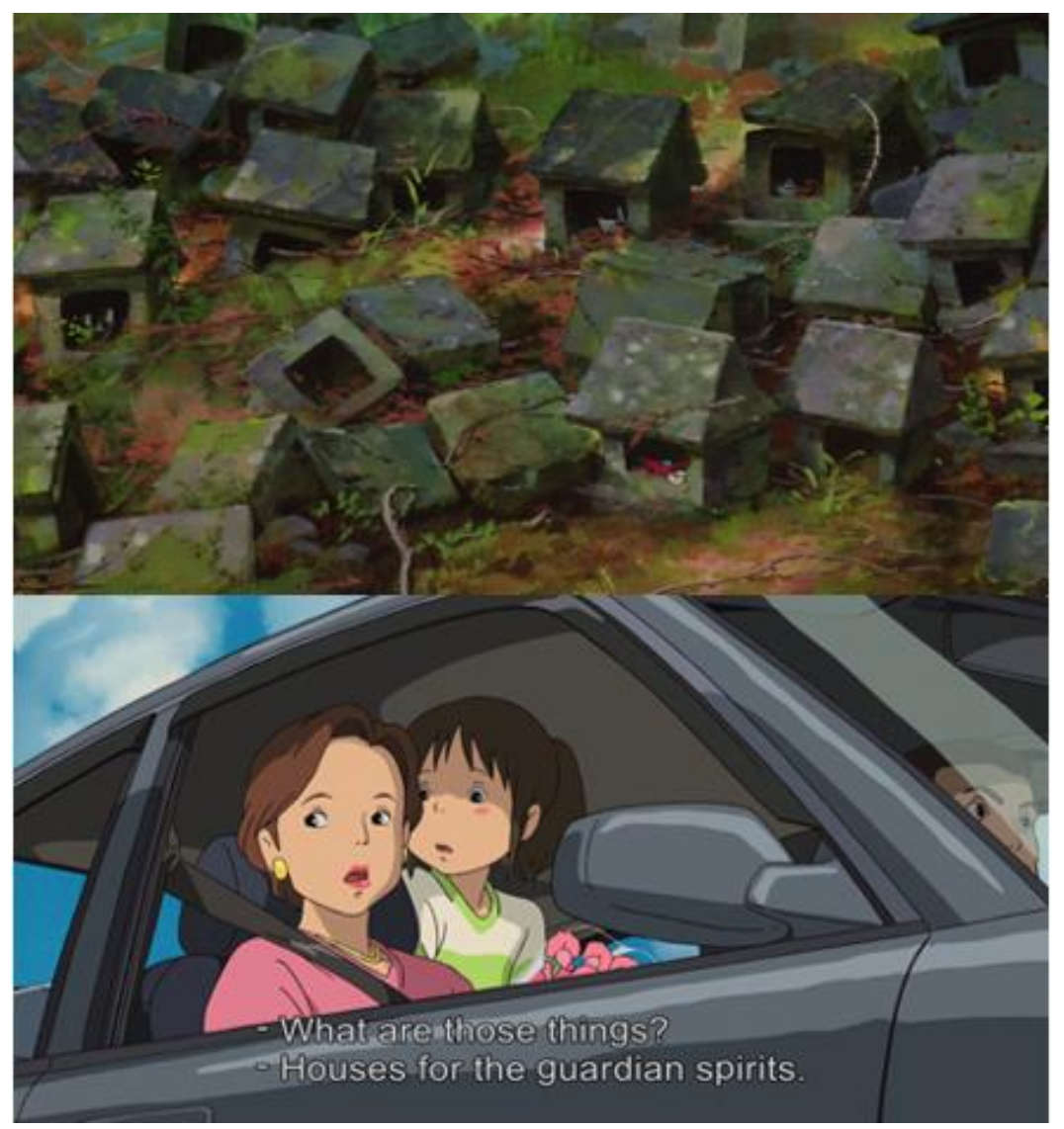

Page | 45

Gambar 7. Hokora yang dilewati keluarga Chihiro sebelum sampai Gerbang Merah (Red Gate)

Sumber : https://movies.stackexchange.com, diakses pada tanggal 24 Mei 2021, pukul 18.29 WIB. 


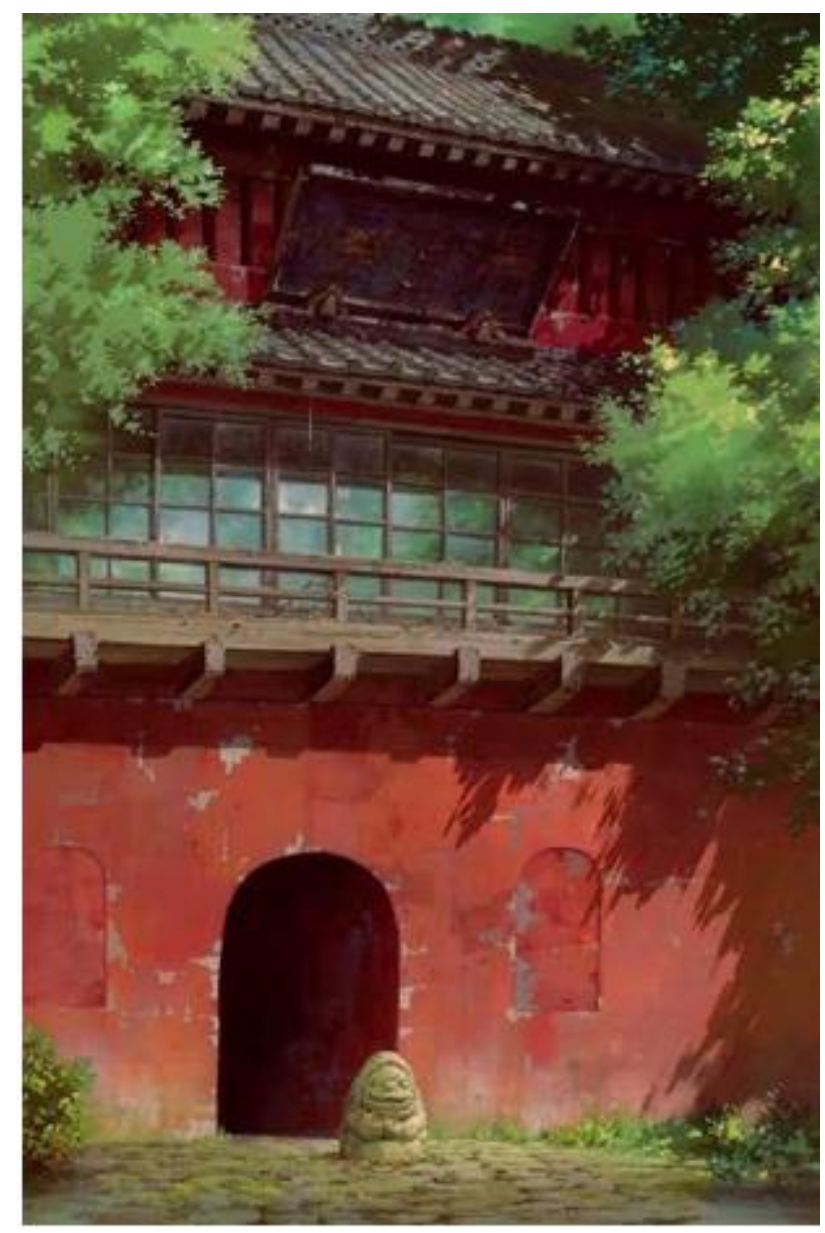

\section{Gambar 8. Gerbang masuk dunia Dewa di film Spirited Away.}

Sumber : https://aminoapps.com, diakses pada tanggal 30 September 2019, pukul 13.18 WIB.

Terdapat perbedaan yang sangat jelas terhadap visual gerbang ini di awal film dan akhir film. Saat Chihiro masuk ke dalam dunia Dewa, gerbang ini sangat terkesan sakral dengan warna dan desain yang kental dengan sifat arsitektural bangunan Shintoisme (kuil, torii, dsb), tapi di akhir film saat Chihiro dan keluarganya berhasil keluar dari dunia tersebut, visual gerbang tersebut berubah menjadi warna putih, dari bebatuan, dengan tanaman rambat yang memenuhi dinding dan tampak tidak terawat. Begitupun dengan desain patung batu (Dosojin) di depan pintu gerbang, pada saat masuk, patung batu memiliki dua wajah yang menghadap depan dan belakang, sedangkan pada saat keluar, patung tersebut hanya memiliki satu wajah menghadap ke arah jalan tanah darimana mobil Chihiro datang.

Hal ini dijelaskan dalam website fandom Studio Ghibli, bahwa pada saat dunia Dewa terbuka visual gerbang yang terlihat adalah gerbang merah (Red Gate). Gerbang Merah merupakan penghubung yang menghubungkan dunia manusia dan dunia para Dewa/roh. Gerbang tersebut berbentuk terowongan yang tembus ke dalam sebuah bangunan yang memiliki 3 buah gerbang identik. Chihiro keluar dari gerbang paling kanan menuju sebuah tempat yang terlihat seperti stasiun kereta api dengan kursi-kursi tunggu yang kosong. Pada saat mereka keluar dari ruangan tersebut, fasad bangunan tersebut memiliki menara jam yang cukup tinggi. Sedangkan pada saat Dunia Dewa tertutup dari dunia manusia, maka visual yang terlihat adalah gerbang putih dan tak terawat (White Gate)[7]. 


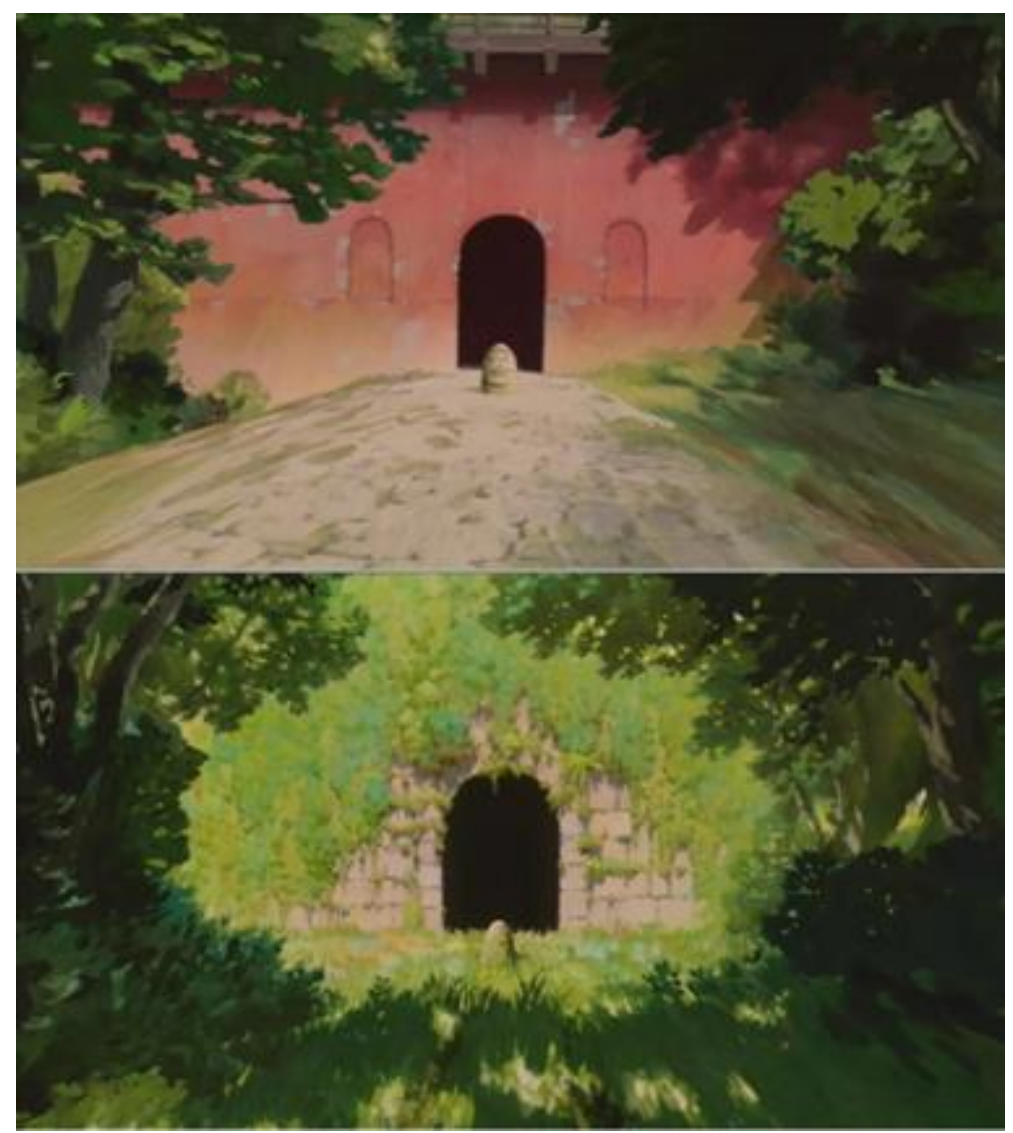

Gambar 9. Perbedaan Gerbang Masuk Dunia Dewa di Awal dan Akhir Film.

Sumber : https://id.pinterest.com/pin/350717889702049346/?lp=true, diakses pada tanggal 07 Oktober 2019, Pukul 11.05 WIB

Perbedaan desain pada gerbang ini berhubungan erat dengan "apa dan siapa” yang disambut oleh gerbang tersebut. Menurut penjelasan sebelumnya, Gerbang Merah terlihat seperti itu pada saat dua dunia terbuka. Hal ini bertujuan untuk menyambut pengunjung agung (Dewa, Roh Agung, dsb). Karena itulah desain yang terlihat adalah desain dengan nuansa Shintoisme; merah, kolom-kolom kayu, jendela berjajar, yang mengingatkan pada dinding Kuil Shinto ataupun pagar pembatas gedung di Kuil-Kuil Shinto. Bentuk dari gerbang tersebut juga berkesan seperti dinding kastil pada bangunan tradisional Jepang, namun warna merah memberikan kesan shinto yang kental sehingga terasa lebih sakral.

Tujuan dari visual ini adalah kesakralan yang ingin diperlihatkan gerbang tersebut sebagai pintu masuk ke tempat Dewa dan Roh Agung, karena merekalah yang disambut gerbang tersebut, dan bukan manusia. Sedangkan Gerbang dengan batuan putih dan tumbuhan tak terawat dan merambati tempat tersebut terkesan tidak sakral, atau rendah, ditujukan untuk menyambut manusia dan tidak mengarah kemanapun selain terowongan biasa. Kedua hal ini memperlihatkan kelas yang berbeda tergantung pada zat yang disambut gerbang tersebut.

Pada awal film, waktu itu merupakan waktu terbukanya gerbang ke Dunia Dewa, sehingga yang disambut gerbang tersebut adalah Dewa-dewa dan Roh Agung, hanya sebuah kebetulan atau takdir yang membawa keluarga Chihiro datang kesana pada waktu yang tidak tepat bagi mereka. Sedangkan di akhir film, adalah waktu-waktu biasa, tidak ada Dewa dan Roh Agung yang disambut sehingga visual yang terlihat adalah visual yang ditujukan untuk manusia biasa. 


\subsection{Warna dan Bentuk Gerbang}

Dalam budaya Jepang, warna merah merupakan warna yang dianggap tua dan sangat penting. Merah banyak digunakan dalam kehidupan sehari-hari, seperti pada berbagai penamaan dan lainnya. Warna merah di Jepang melambangkan matahari, dan juga menjadi warna keagamaan dan menjadi warna dasar pada kuil-kuil shinto[8]. Secara khusus, warna merah pada ajaran Shinto melambangkan para Dewa-dewa Shinto. Banyak lukisan Dewa dengan warna merah yang menonjol. Gerbang (Torii) dan kuil-kuil shinto juga diwarnai dengan warna tersebut. Warna ini dipercaya sebagai warna yang memiliki kekuatan, kesucian, kesembuhan, dan hal lain yang memiliki nilai-nilai kesakralan dan spiritualisme[9].

Dalam Film Spirited Away, warna merah dan bentuk arsitektural Jepang tradisional sangat kental terasa dari lokasi cerita tersebut. Dunia Spirited Away tempat Chihiro terjebak di dalamnya merupakan tempat yang dipenuhi warna merah dan bentuk-bentuk arsitektural kuil maupun kastil di Jepang. berbagai macam bangunan dan dekorasi diwarnai dengan warna-warna merah dan aksen-aksen dekorasi Jepang yang cukup mudah dikenali.

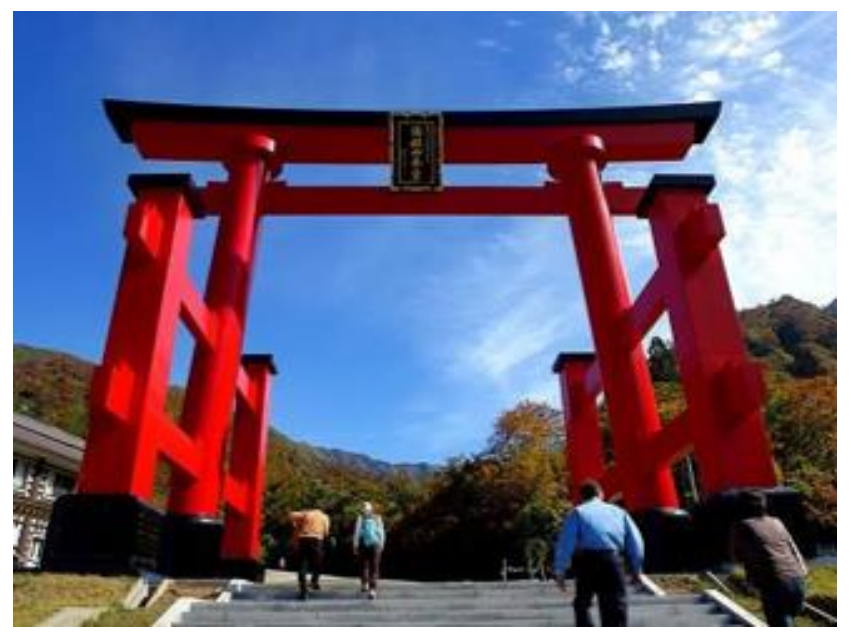

Gambar 10. Gerbang (Torii) yang biasa ditemukan di Jepang.

Sumber : https://www.worldreligionnews.com/religion-news/what-is-the-significance-of-a-torii, diakses tanggal 02

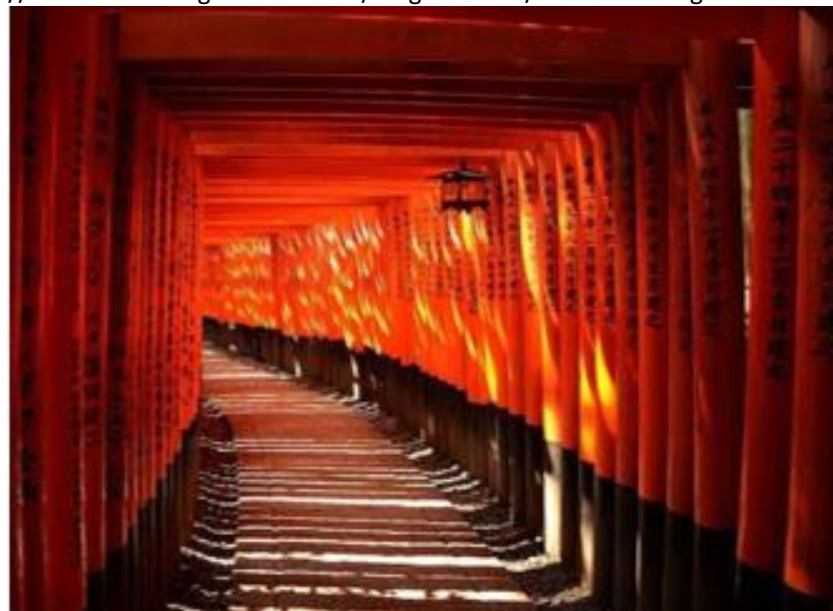

Gambar 11. Fushimi Inari, Jajaran 10.000 Gerbang (Torii) yang ikonik di Kyoto.

Sumber : https://www.masterpiece-of-japanese-culture.com/category/travel, diakses pada tanggal 02 Oktober 2019, Pukul 10.59 WIB 


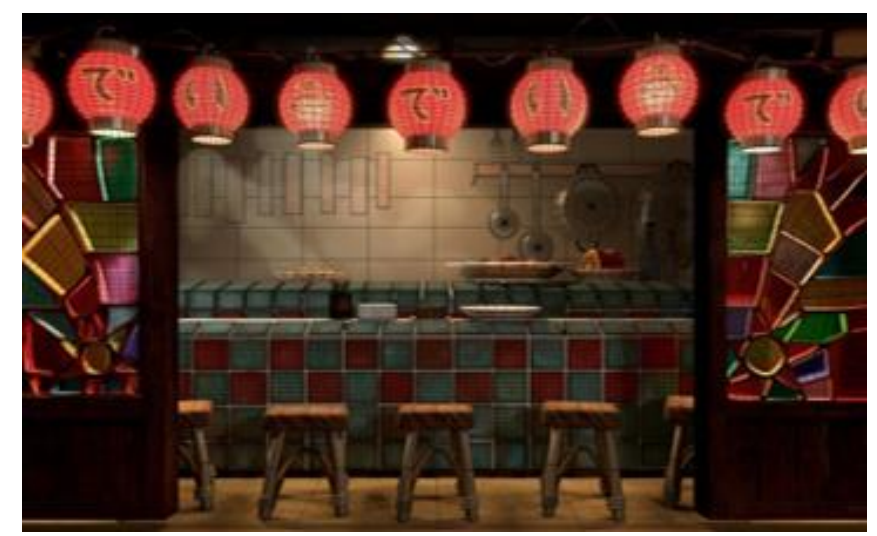

Gambar 12. Salah satu restoran dengan aksen merah di adegan film.

Sumber : https://www.artstation.com/artwork/nQDwDO, diakses pada tanggal 02 Oktober 2019, Pukul 11.08 WIB.

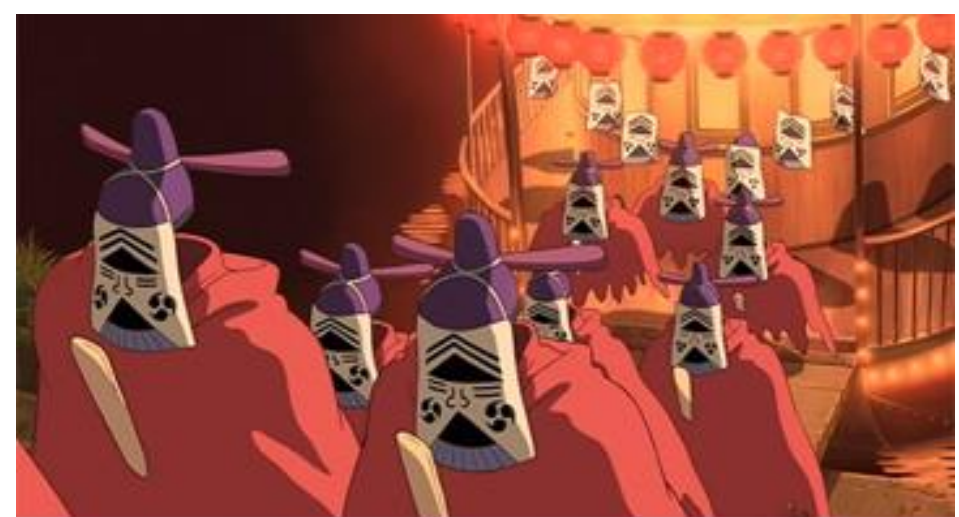

Gambar 13. Adegan saat para 'spirit' mendatangi wilayah pertokoan dan Rumah Pemandian.

Sumber: https://myanimelist.net/featured/1034/The_World_of_Spirits_and_Ghosts_in_Spirited_Away, Diakses pada 12 September 2020, Pukul 11.32 WIB

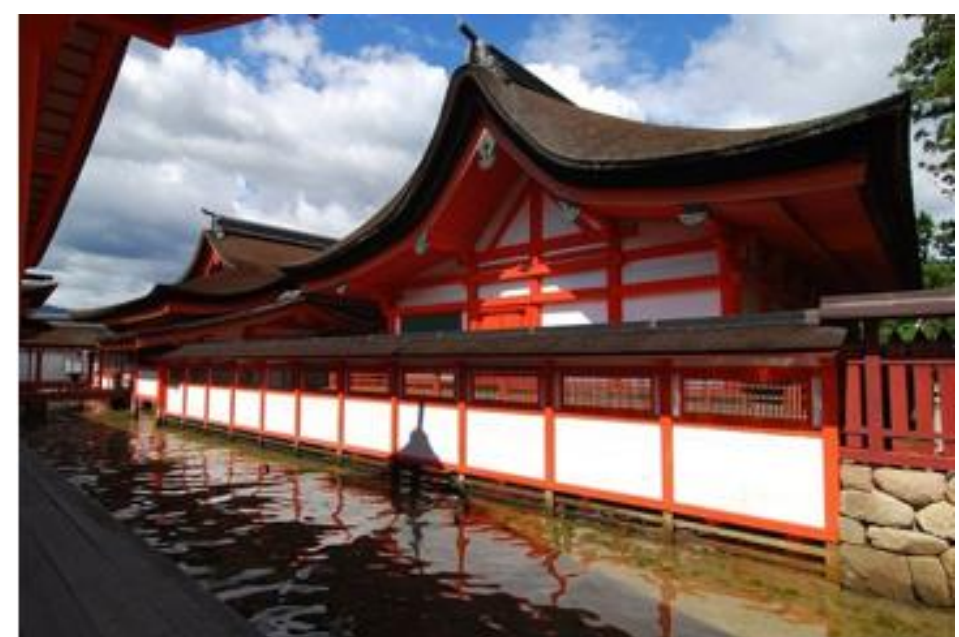

Gambar 14. Kuil Itsukushima, di Hiroshima, tipikal arsitektural periode Heian,

Sumber: http://www.miyajima-wch.jp/jp/itsukushima/, diakses pada tanggal 07 Oktober 2019, Pukul 12.35 WIB 
Gerbang Merah didesain dengan mengambil nilai-nilai yang sama. Bentuknya dibuat seperti kastil tradisional dengan dinding tinggi, dan jajaran jendela yang terletak diatas seakan-akan seperti benteng atau pagar. Jenis Bangunan seperti ini mulai terlihat pada arsitektural Jepang periode Heian hingga Edo, dimana material berat seperti batu dan mortar mulai digantikan dengan lantai kayu, dengan material cedar (sugi) yang populer sebagai interior sedangkan pinus (matsu) dan kayu larch (aka-matsu) sebagai struktur[10], pada periode Edo, kebanyakan bangunan dibuat tinggi, dengan batu pada level bawah[11]. Warna dan material yang dipakai Gerbang Merah (Red Gate) merupakan warna merah dan hitam, sehingga daripada berkesan sebagai kastil, bangunan ini terlihat seperti bagian dari kuil.

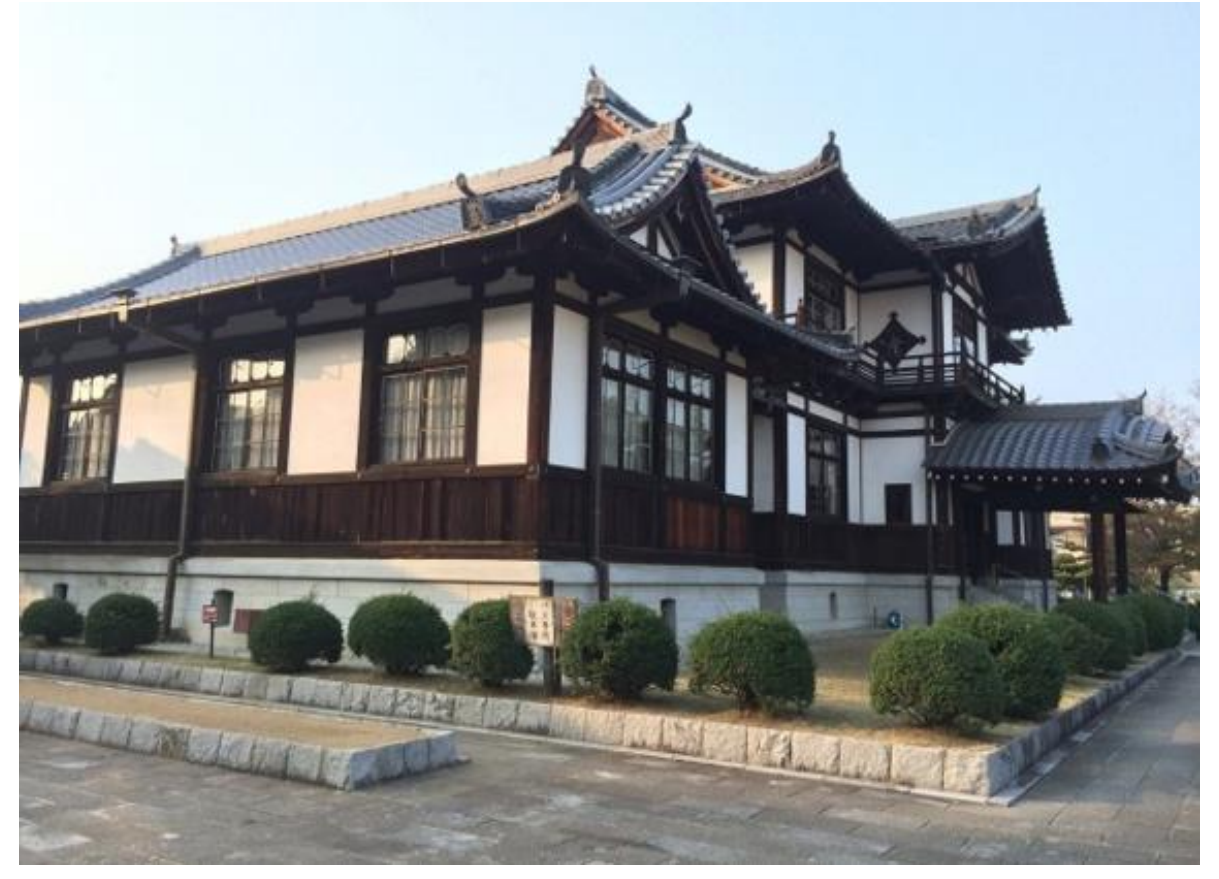

\section{Gambar 15. Bangunan Periode Edo,}

Sumber : https://www.pinterest.ca/travelarrangeja/rural-nara-imaicho/, diakses pada tanggal 07 Oktober 2019, Pukul 12.39 WIB 


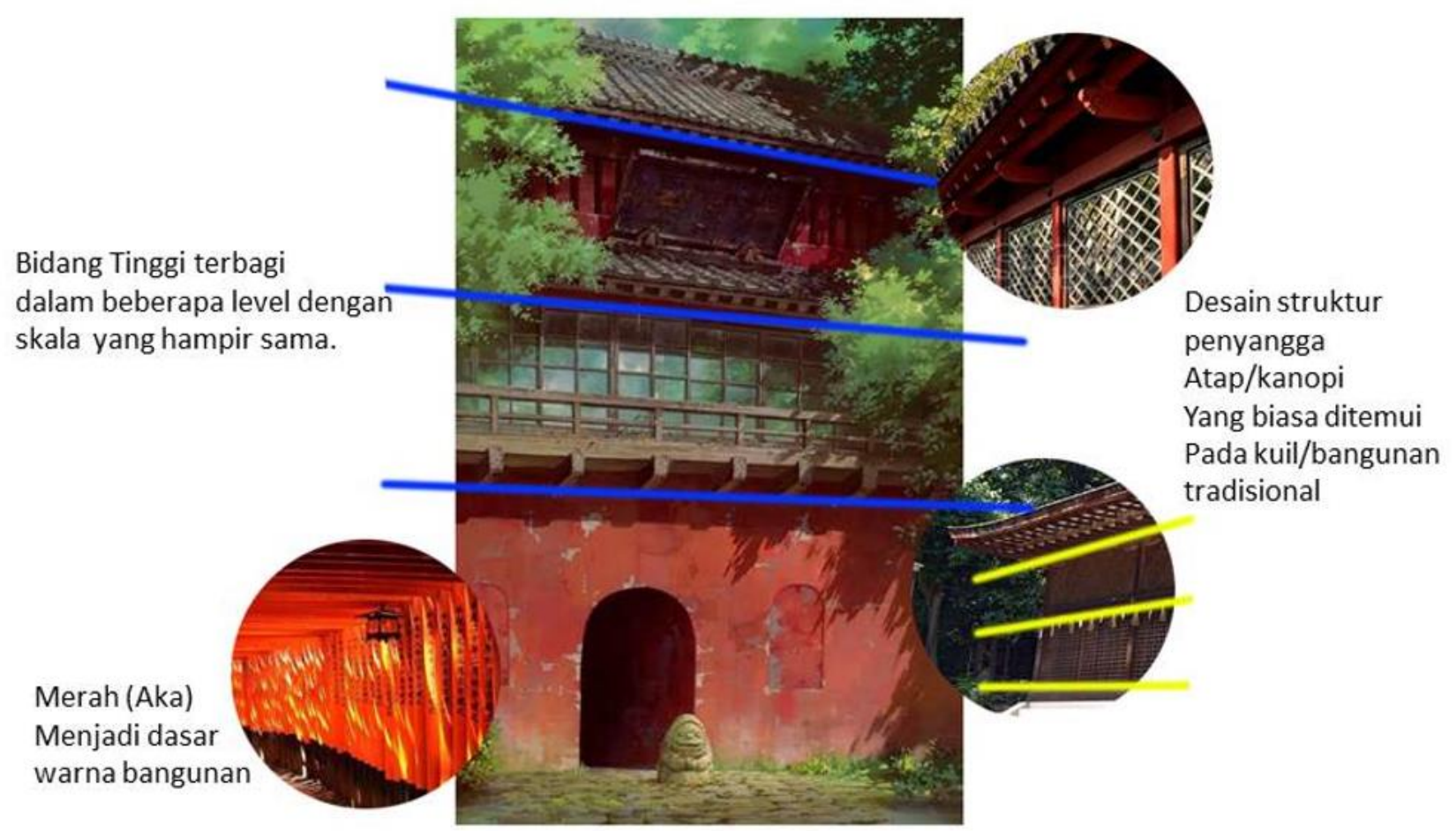

Gambar 16. . Kajian visual Gerbang Spirited Away, Gambar dari berbagai sumber, dikomposisikan oleh pribadi; 2019

Dengan melihat dari komposisi warna juga bentuk arsitektural gerbang tersebut, dapat disimpulkan bahwa gerbang Merah (Red Gate) didesain dengan mengacu pada bangunan-bangunan shintoisme dengan warna merah dan struktur yang biasa dikenali di kuil-kuil Shinto di Jepang.

\subsection{Akhir Kisah Film}

Di akhir film, Chihiro berhasil keluar dari dunia tersebut dan menyelamatkan kedua orang tuanya dari kutukan, dibantu oleh teman-teman barunya, juga kegigihan dan keberaniannya. Setelah dia berhasil melepas kutukan, Chihiro diminta untuk kembali melewati jalan yang dulu dilewatinya saat masuk dan dilarang untuk menoleh ke belakang hingga dia selesai keluar dari gerbang. Chihiro berhasil keluar tanpa menoleh sampai dia keluar dari gerbang. Namun gerbang tempat dia keluar sama sekali berbeda dengan gerbang saat dia masuk. Dari penampakan gerbang tersebut, ada kemungkinan dia salah mengambil jalan pada saat keluar dari stasiun kereta. Akan tetapi di tempat yang sama juga terdapat mobil orang tuanya yang terparkir seperti saat mereka masuk. Perbedaan yang kentara hanyalah dedaunan rontok dari pepohonan sekitar menutupi sebagian tubuh mobil.

Keadaan di sekitar pun tidak tampak seperti di awal film. Di akhir film, tumbuhan di sekitar gerbang tumbuh dengan liar dan tak terurus, dinding gerbang pun dipenuhi lumut dan tanaman rambat yang tumbuh liar menutupi hampir seluruh dinding gerbang. Material dan warna gerbang juga sangat berbeda. Saat Chihiro keluar, gerbang tersebut tidak berwarna merah dan didesain dengan sifat arsitektural Shintoisme, tapi hanya seperti gerbang terowongan tua pada umumnya dengan batuan-batuan putih yang tak terurus. 


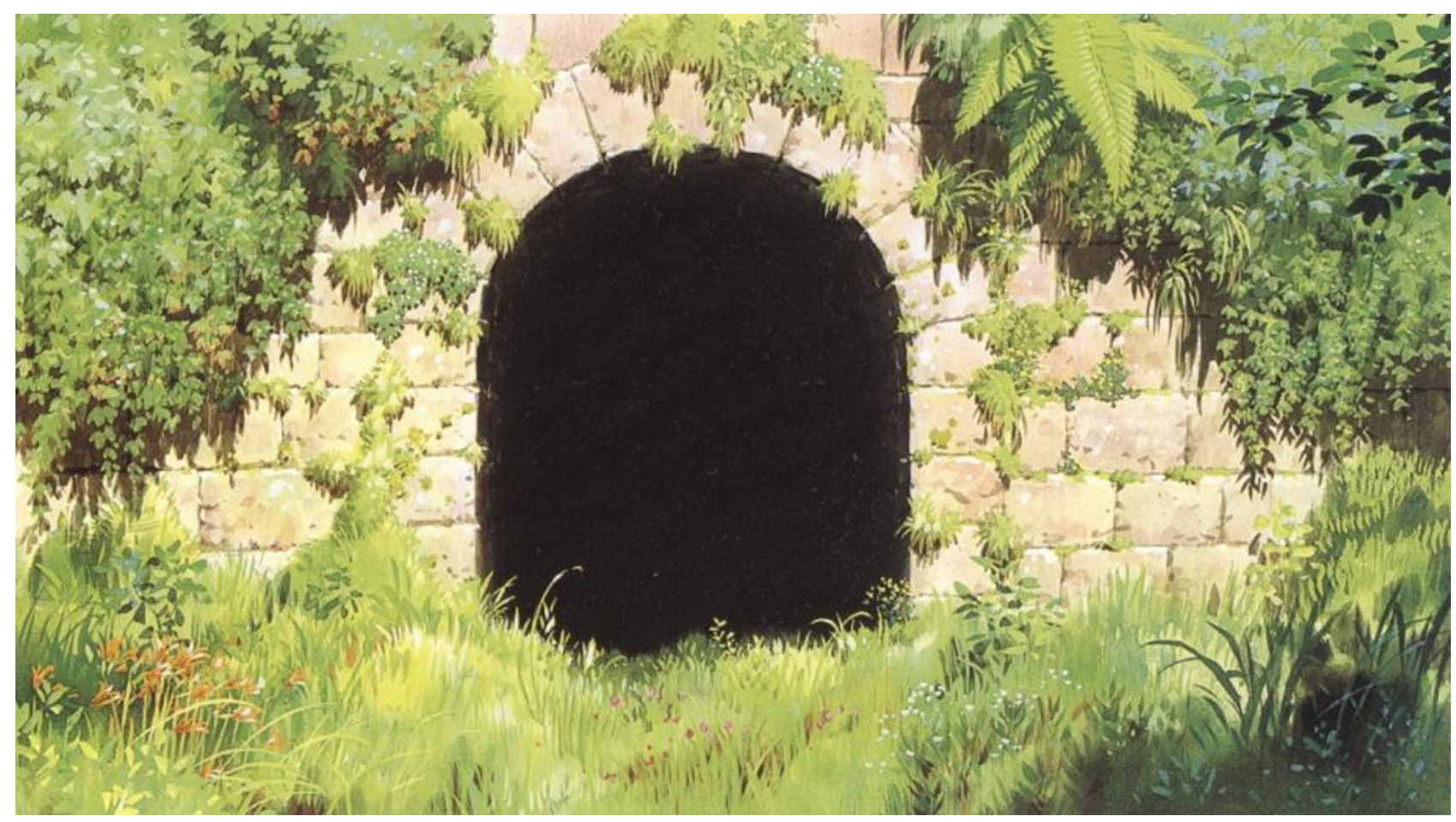

Gambar 17. Visual Gerbang pada saat Chihiro dan keluartganya kembali ke dunia manusia. Terdiri dari batu-batu polos tanpa perawatan dan tanaman rambat serta lingkungan yang tidak terurus.

Sumber: https://wallpaperzen.org/studio-ghibli-wallpaper-mobile-backgroun

Perbedaan lainnya adalah Patung Batu yang ada di depan gerbang, pada awal film, patung tersebut memiliki dua wajah yang menghadap depan dan belakang. Sedangkan pada akhir film, patung batu tersebut hanya memiliki satu wajah menghadap ke depan, ke arah jalan masuk setapak dimana mobil orangtua Chihiro diparkir.

Menurut website resmi dari Spirited Away dan Studio Ghibli, patung ini disebut "Dosojin Statue", pada konten film, patung ini merepresentasikan dua penyihir penguasa dunia yang dimasuki Chihiro dan orangtuanya, Yubaba dan Zeniba[12].

Dosojin sendiri (道祖神, Dewa Jalan/Perjalanan) merupakan nama jenerik untuk Dewa Shinto yang banyak dipuja di wilayah Kanto dan sekitarnya, dipercaya sebagai penjaga yang berhubungan dengan area-area seperti perbatasan, jalanan, dan penghubung jalan. Dewa ini dipercaya melindungi para pejalan kaki, wisatawan, penjelajah, musafir dari gangguan roh jahat dan penyakit[13]. Dosojin sering ditemukan di daerah pedesaan, seperti di area perbatasan, jalan menuju gunung, atau persimpangan jalan. Sedangkan di perkotaan sering terlihat di sudut jalan atau dekat jembatan[14]. Selain Dosojin, di sekitar Torii dan gerbang juga terdapat banyak sekali Hokora (miniatur kuil shinto) yang dipercaya sebagai kuil dari Dosojin. Ketiga tanda visual ini; Torii, Hokora, dan Dosojin menggambarkan keluarga Chihiro yang melakukan perjalanan melewati sebuah perbatasan, dalam cerita ini perbatasan ke dunia dewa/roh. 
O J u r n a I

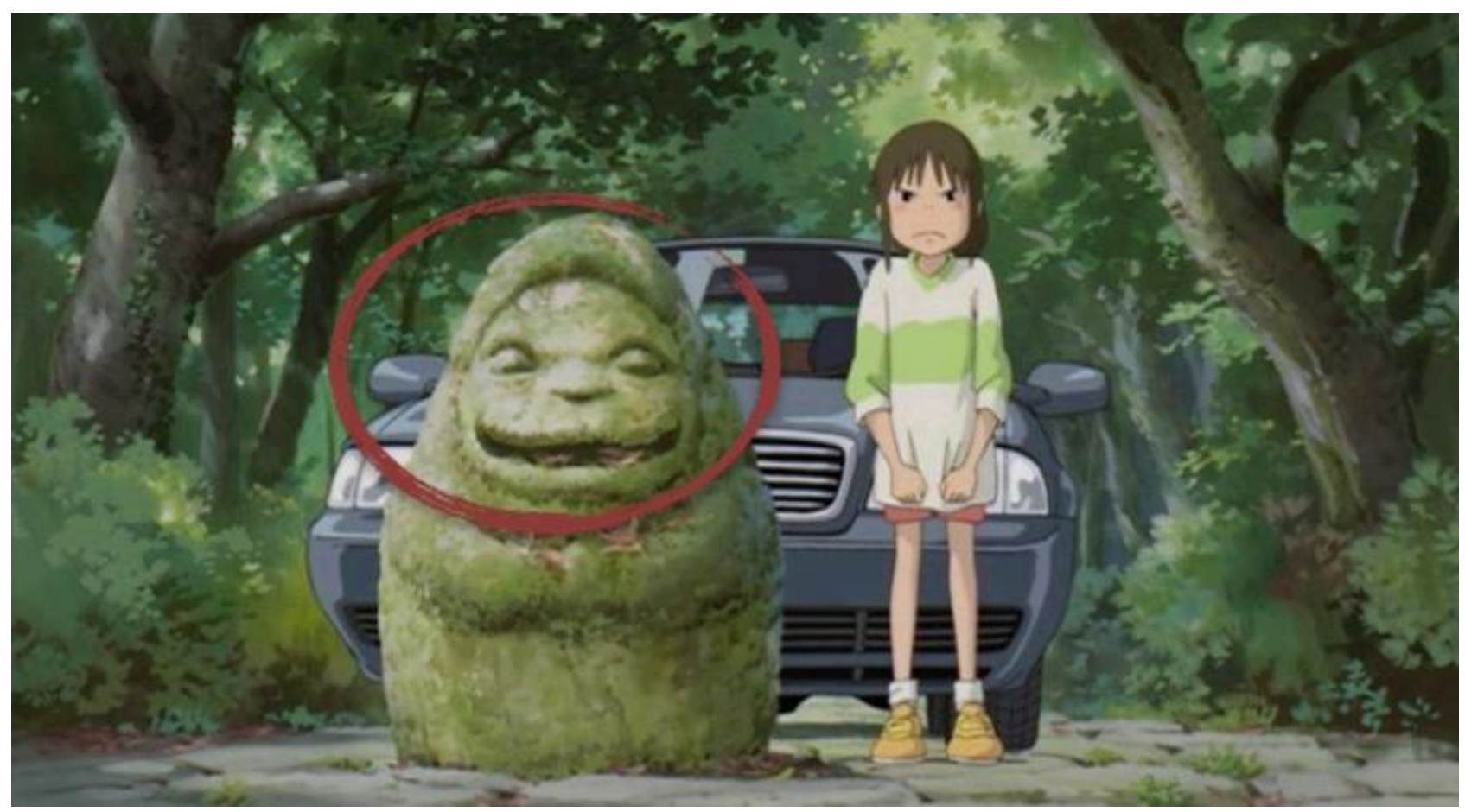

Gambar 18. Dosojin memiliki dua wajah ke depan dan belakang di awal film.

Sumber : https://ghibli.fandom.com/wiki/D\%C5\%8Dsojin Statu, diakses pada tanggal 14 Oktober 2019, Pukul 10.08 WIB

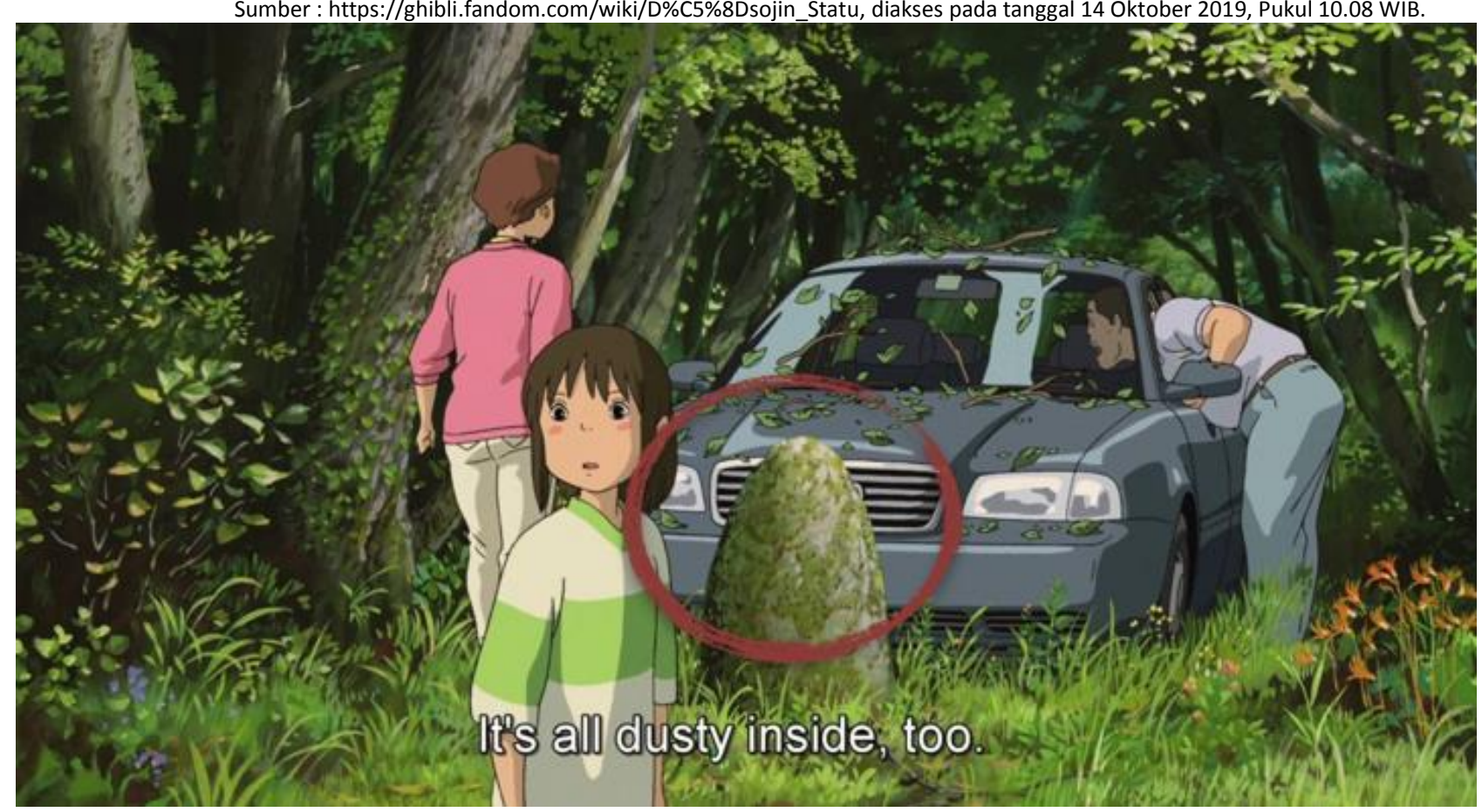

Gambar 19. Dosojin memiliki satu wajah ke arah jalan masuk dari arah Chihiro dan orangtuanya datang dengan mobil.

Sumber: https://id.pinterest.com/pin/503418064594751659/?/p=tru, diakses pada tanggal 14 Oktober 2019, Pukul 10.11 WIB

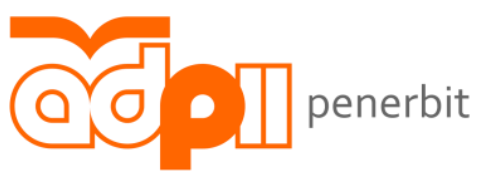


Keberadaan Dosojin ini memperlihatkan kesakralan jalan yang akan Chihiro lewati, dan keadaan yang berbeda memperlihatkan perbedaan gerbang tersebut. Pada saat Dosojin memiliki dua muka depan dan belakang, itu adalah saat dimana gerbang terbuka ke kedua arah, Dunia Dewa/Roh dan Dunia Manusia. Sehingga gerbang merah (Red Gate) terlihat agung dan berkesan spiritual, hal ini karena apa yang disambut gerbang tersebut adalah para Dewa dan Roh Agung. Sedangkan pada saat Chihiro keluar dari dunia tersebut, Dosojin hanya memiliki satu wajah yang menghadap ke arah depan (ke arah mobil) hal ini memperlihatkan bahwa gerbang dunia yang terbuka hanyalah Dunia Manusia, dan Dunia Dewa tertutup. Karena itulah visual gerbang yang terlihat adalah gerbang batu biasa yang sama sekali tidak mewakili spiritualitas Shinto (White Gate). Karena perbedaan tamu yang disambut itulah maka desain kedua gerbang tersebut berbeda. Perbedaan warna, material, dan desain dari gerbang di awal dan akhir film dikarenakan konsep spiritual Shinto, saat menyambut para Dewa dan saat tidak dilakukan penyambutan Dewa. Chihiro dan keluarganya masuk pada saat yang tidak tepat bagi manusia.

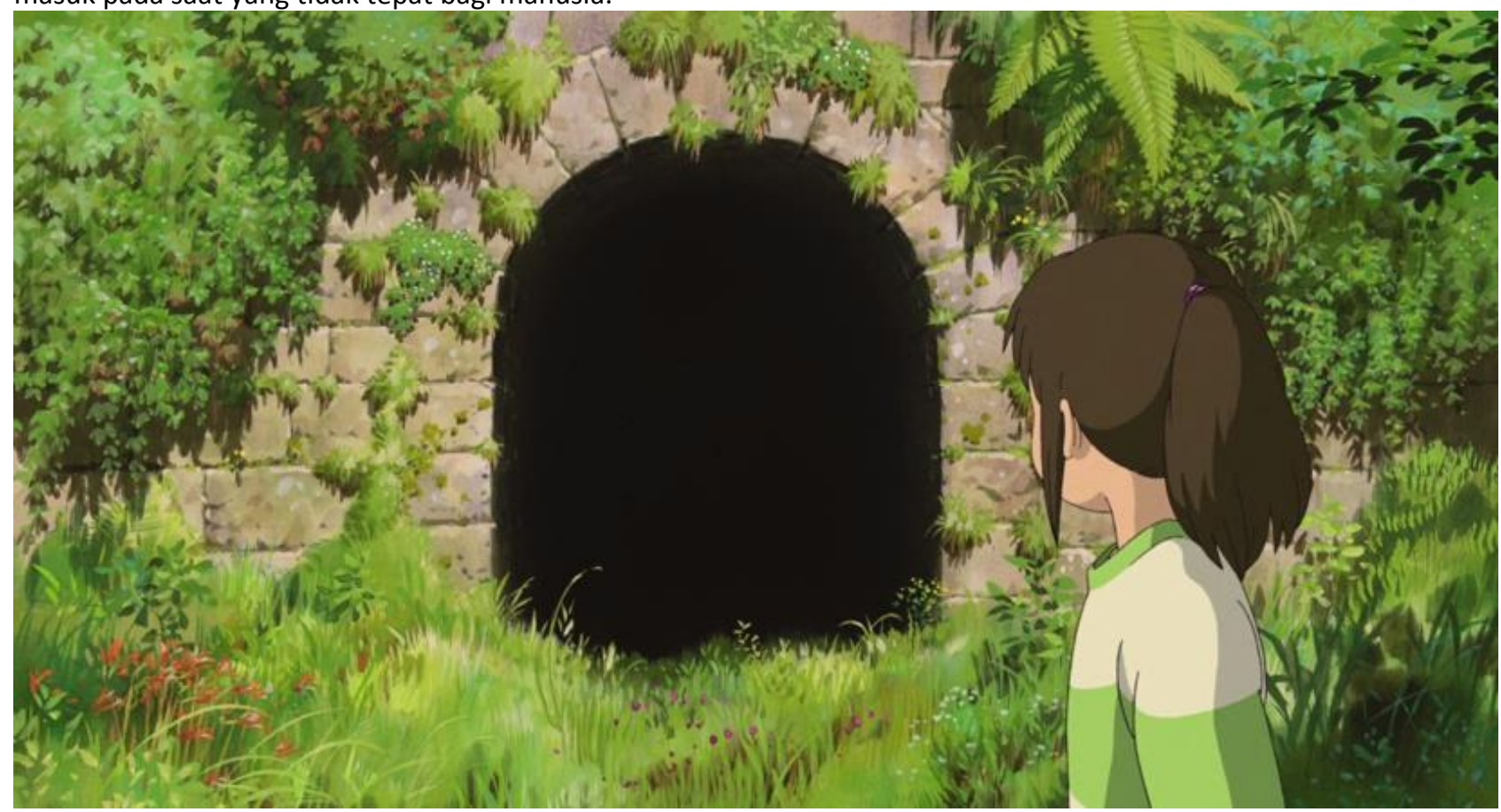

\section{Gambar 20. Adegan akhir film saat Chihiro melihat gerbang tersebut untuk terakhir kalinya.}

Sumber : http://fanaru.com/spirited-away/image/205871/chihiro-wallpaper/, diakses pada tanggal 24 Oktober 2019, pukul 11.39 WIB

\section{Kesimpulan.}

Perbedaan yang sangat signifikan pada desain gerbang di awal dan akhir film Spirited Away tidak pernah dijelaskan secara eksplisit, baik itu dalam film maupun oleh Hayao Miyazaki. Namun apabila mengkajinya lewat tanda-tanda visual dari perspektif shintoisme pada warna dan desain arsitektur di film, juga pada nilai-nilai shintoisme yang diangkat dalam cerita tersebut, peneliti dapat menemukan arti dari perbedaan tersebut.

Dari pembahasan mengenai tanda-tanda visual pada bentuk, warna, dan material dari arsitektural kedua gerbang, nuansa Shinto terasa sangat kental. Hal ini juga diperkuat oleh tanda-tanda visual lain seperti kemunculan Torii, Hokora, dan Dosojin di sekitar gerbang. Cerita dan karakter pada film Spirited Away juga sangat kental dengan shintoisme, diantaranya para Dewa, Yubaba, dan Misogi (Memandikan diri sebagai purifikasi). Mengetahui bahwa keseluruhan film ini kental dengan nuansa Shintoisme, maka kaji tanda-tanda visual pada kedua desain gerbang (Red Gate dan White Gate) dapat dilakukan berdasarkan nilai-nilai Shintoisme.

Dengan memanfaatkan Konsep Triadik Sumbo Tinarbuko, analisis semiotika komunikasi visual pada kedua desain gerbang pun dapat dideskripsikan sebagai berikut: 
- Teori: Studi literatur terhadap warna dan bentuk arsitektural gerbang didasari dengan prinsip-prinsip shintoisme yang menjadi tema utama pada film memperlihatkan hubungan yang sangat erat antara nilai-nilai shintoisme pada desain gerbang di awal dan akhir film.

- Konteks: Tempat Chihiro dan keluarganya masuk adalah dunia para Dewa, tempat para Dewa dan Roh dapat membersihkan diri mereka dengan cara mandi di Pemandian. Hal ini berhubungan dengan kegiatan purifikasi dalam Shintoisme yang disebut Misogi. Saat Keluarga Chihiro masuk, gerbang yang mereka lewati berbentuk dinding mulus berwarna merah dengan fasad arsitektural yang mengesankan nuansa kuil shinto. Pada saat Page | 55 mereka keluar di akhir film, desain gerbang tersebut berubah menjadi gerbang biasa dengan susunan batu putih dan dipenuhi tanaman merambat yang tidak terurus.

- Konten: keseluruhan film bertemakan nilai-nilai shintoisme dari mulai cerita, karakter, dan arsitekturalnya terinspirasi dari nilai-nilai tersebut. Tidak terkecuali dengan desain gerbang di awal dan akhir film. Desain gerbang di awal film (Red Gate) berhubungan erat dengan nilai-nilai Shintoisme, khususnya dari segi arsitektural yang terinspirasi dari kuil Shinto. Hal ini berhubungan dengan waktu dan objek yang disambut gerbang tersebut. Sedangkan gerbang di akhir film (White Gate) dianggap gerbang biasa karena pada saat itu gerbang tidak sedang menyambut tamu agung (Dewa-dewa dan Roh). Wajah Dosojin yang terdiri dari dua wajah pada saat Red Gate terlihat dan satu wajah pada saat White Gate terlihat menjadi petunjuk penting.

- Media: Nilai-nilai Shintoisme ini disampaikan melalui alur cerita, karakter, warna dan desain bangunan dalam film. Tanda-tanda visual dapat dikenali dari warna merah, bentuk arsitektural kuil shinto, keberadaan Torii, Hokora, dan Dosojin.

Hasil Analisa: Dari keempat poin analisa tersebut disimpulkan bahwa perbedaan desain gerbang merah dan putih didasari oleh nilai-nilai shintoisme dalam menyambut tamu Dewa/Roh. Dimana gerbang merah yang memiliki karakteristik kuil Shinto dan Dosojin dua muka merupakan gerbang yang ditujukan untuk menyambut Dewa dan Roh Agung pada waktu-waktu tertentu (dalam film dikisahkan sekitar sore/senja hari), sedangkan gerbang putih dengan Dosojin satu muka adalah gerbang biasa yang ditujukan untuk mata manusia pada saat Dunia Dewa tertutup dan tidak menyambut tamu. Hal ini berhubungan erat dengan apa, siapa, dan waktu penyambutan, antara Dewa/Roh (Kami) atau manusia biasa. Sehingga perbedaan desain gerbang pada dua scene ini menjadi perlu dan penting, karena hal ini menegaskan status dunia yang dimasuki oleh Chihiro dan keluarganya.

Spirited Away merupakan film yang dilatarbelakangi nilai shintoisme yang kental, dari mulai cerita, desain arsitektural, dan desain karakter-karakternya. Isu yang diangkat oleh film ini sangat positif seperti isu lingkungan, tata krama, penghormatan pada sipiritualisme, kemandirian, keberanian, dan pertemanan. Film ini tidak termasuk baru, namun semua segi dari film ini layak untuk diteliti. Banyak penelitian yang dihasilkan dari film tersebut. Namun perbedaan desain arsitektural gerbang merah dan putih belum secara spesifik diteliti. Dengan mengkaji dari segi arsitektural gerbang tersebut, diharapkan dapat membantu penelitian berikutnya mengenai topik sejenis. Penelitian ini juga diharap mampu memberikan data kualitatif bagi kajian gerbang maupun arsitektural film Spirited Away secara keseluruhan, dan juga dapat memberikan informasi terkait pengembangan desain arsitektur dalam pembuatan animasi, khususnya arsitektur yang berhubungan dengan budaya dan spiritual di suatu daerah.

\section{Referensi}

[1] Admin, "Spirited Away", British Board of Film Classification, 2003, [Online]. Tersedia : https://www.bbfc.co.uk/releases/spirited-away-2003 [Diakses pada tanggal 30 September 2019, pukul 11:42 WIB]

[2] S. Tinarbuko, "Semiotika Tanda Verbal dan Tanda Visual Iklan Layanan Masyarakat", Panggung Jurnal Seni Budaya, Vol. 26, no. 2, pp 181-194, Juni. 2016

[3] A. Dewi, "Pengembangan Kompetensi Multiliterasi Desain Berbasis Pada Penerapan Tradisi Komunikasi Di Era Indonesia 4.0", JDI, vol. 1, no. 1, pp. 1 - 6, Jan. 2019.

[4] I. Averbuch, "The gods come dancing : a study of the Japanese ritual dance of Yamabushi Kagura", "Cornell East Asia series", Ithaca, N.Y., East Asia Program Cornell University, xvi, 326 p, 1995

[5] J.W. Boyd, "Shinto Perspectives in Miyazaki's Anime Film "Spirited Away"”, Journal of Religion \& Film, vol. 8, No. 3, Artikel 4, 2016. 
[6] Admin, "Spirit Realm", Ghibli Fandom, 2019, [Online]. Tersedia: https://ghibli.fandom.com/wiki/Spirit_Realm [diakses 02 Oktober 2019, pukul 13.13 WIB]

[7] A. Namiko, "Japanese Conception Of Red : Is Red The Color Of Love?", ThoughtCo., [Online]. Tersedia: thoughtco.com/japanese-conception-of-red-2028026. [diakses pada tanggal 01 Oktober 2019, Pukul 14.27 WIB.]

[8] M. Schumacher, "Color Red in Japanese Mythology", On Mark Productions, 2010, [Online]. Tersedia: https://www.onmarkproductions.com/html/color-red.html, [Diakses pada tanggal 01 Oktober 2019, Pukul Page | 56 14.33 WIB.]

[9] K. Zwerger, Klaus, Wood and Wood Joints: Building Traditions of Europe, Japan and China, Second, Revised and Expanded Edition, Basel Switzerland: Birkhauser Architecture, 2012.

[10] M. Bussagli, Oriental Architecture II, New York: Rizzoli Publications, 1989

[11] Admin, "Dosojin Statue", Ghibli Fandom, 2019, [Online]. Tersedia: https://ghibli.fandom.com/wiki/D\%C5\%8Dsojin_Statue, [Diakses pada tanggal 14 Oktober 2019, Pukul 10.56 WIB.]

[12] K. Kawamura, "Dōsojin : Encyclopedia of Shinto". Kokugakuin University Jepang, 2005, [Online]. Tersedia: http://eos.kokugakuin.ac.jp/modules/xwords/entry.php?entrylD=205 [Diakses pada tanggal 14 Oktober 2019, pukul 11.05 WIB]

[13] M. Schumacher, “DŌSOJIN 道祖神 (Dōsojin, Dousojin) PROTECTIVE STONE MARKERS BOTH SHINTŌ \& BUDDHIST", On Mark Productions, 1995, [Online]. Tersedia: http://www.onmarkproductions.com/html/dosojin-stone-markers.shtml [Diakses pada tanggal 24 Oktober 2019, pukul 11.22 WIB] 